\title{
The Ability of Cyanobacterial Cells to Restore UV-B Radiation Induced Damage to Photosystem II is Influenced by Photolyase Dependent DNA Repair
}

\author{
István-Zoltán Vass, Péter B. Kós, László Sass, Csaba I. Nagy and Imre Vass* \\ Biological Research Center of the Hungarian Academy of Sciences, Institute of Plant Biology, Szeged, Hungary \\ Received 2 July 2012, accepted 15 October 2012, DOI: 10.1111/php.12012
}

\begin{abstract}
Damage of DNA and Photosystem-II are among the most significant effects of UV-B irradiation in photosynthetic organisms. Both damaged DNA and Photosystem-II can be repaired, which represent important defense mechanisms against detrimental UV-B effects. Correlation of Photosystem-II damage and repair with the concurrent DNA damage and repair was investigated in the cyanobacterium Synechocystis PCC6803 using its wild type and a photolyase deficient mutant, which is unable to repair UV-B induced DNA damages. A significant amount of damaged DNA accumulated during UV-B exposure in the photolyase mutant concomitant with decreased Photosystem-II activity and D1 protein amount. The transcript level of $p s b A 3$, which is a UVresponsive copy of the $p s b A$ gene family encoding the D1 subunit if the Photosystem-II reaction center, is also decreased in the photolyase mutant. The wild-type cells, however, did not accumulate damaged DNA during UV-B exposure, suffered smaller losses of Photosystem-II activity and D1 protein, and maintained higher level of psbA3 transcripts than the photolyase mutant. It is concluded that the repair capacity of Photosystem-II depends on the ability of cells to repair UV-B-damaged DNA through maintaining the transcription of genes, which are essential for protein synthesis-dependent repair of the Photosystem-II reaction center.
\end{abstract}

Abbreviations: Chl, chlorophyll; CPD, cyclobutane pyrimidine dimer; D1 and D2, reaction center protein subunits of Photosystem-II; DCMU, 3-(3,4-dichlorophenyl)-1, 1-dimethylurea; PSII, Photosystem-II; qPCR, quantitative PCR; UV-B, ultraviolet-B $(280-315 \mathrm{~nm})$ spectral range; 6-4 PPs, thymine-thymine pyrimidine-pyrimidone (6-4) photoproducts.

\section{INTRODUCTION}

Photosynthetic organisms are unavoidably exposed to incident solar light, which not only provides energy to the biosphere via photosynthetic energy conversion, but at the same time can cause damage to biological systems. During evolution of photosynthetic organisms several pathways arose to prevent, or repair

*Corresponding author email: vass.imre@brc.mta.hu (Imre Vass) (C) 2012 Wiley Periodicals, Inc.

Photochemistry and Photobiology (C 2012 The American Society of Photobiology 0031-8655/12 the negative effects of solar radiation. The most detrimental component of sunlight that reaches the Earth's surface is the UV-B $(280-315 \mathrm{~nm})$ spectral range as the more damaging shorter wavelength UV-C radiation is screened out by the ozone layer and other components of the atmosphere.

DNA is particularly sensitive to UV radiation due to its absorption that extends into the physiologically relevant UV-B $(1,2)$ region. Absorption of UV-B photons causes phototransformations in the DNA molecules leading to formation of cyclobutane pyrimidine dimers (CPDs) and thymine-thymine pyrimidine -pyrimidone (6-4) photoproducts (6-4 PPs) among others (3). CPDs are the most predominant $(75-80 \%$ of all UV-B induced damages) and biologically the most relevant UV-B induced lesions in the DNA molecule. As DNA and RNA polymerases cannot read through these lesions their accumulation must be prevented by efficient repair and/or UV screening compounds to maintain functional DNA (4). Photoreactivation with the help of the photolyase enzyme is one of the most important and frequently occurring mechanisms to repair UV-induced DNA photodamages in prokaryotes (3). The structure and function of photolyases is fairly well known: They specifically bind to pyrimidine dimers, flip them out of the DNA duplex and with the aid of photons from the $360-530 \mathrm{~nm}$ range their $\mathrm{FADH}^{-}$ prosthetic group reduces the cyclobutane ring, splitting it up, thus restoring the functional DNA (5). The product of the phrA gene, which codes for a CPD-specific DNA photolyase, is the major photoreactivating factor in the cyanobacterium Synechocystis sp. PCC $6803(6,7)$. Cells lacking this gene are rendered highly sensitive to UV-B radiation (8).

In photosynthetic organisms, pigmented complexes absorb most of the incoming UV-B light (9), therefore besides DNA components the photosynthetic apparatus, especially the Photosystem-II (PSII) complex, is also an important target of UV-B radiation (see Ref.[10]). Within PSII, the primary action site of UV-B radiation is the catalytic manganese cluster of the water oxidizing complex, which leads to inhibition of light-induced electron transport (11-14). This effect is followed by damaging the D1 and D2 protein subunits, which form the backbone of the reaction center complex (15-19). UV-B-induced damage of PSII can be restored via repairing the PSII core complex, which proceeds via de novo synthesis of the damaged D1 and D2 subunits (18). The PSII repair cycle is a complicated process, which has been studied in a great detail in case of photodamage induced by visible light, for reviews see $(20,21)$. Repair of UV-B-induced damages occurs basically in the same way as in 
the case of photodamage of PSII by visible light, with the following main steps: (1) Proteolytic removal of the damaged D1 and D2 protein subunits, (2) Transcription of mRNA from the $p s b A$ and $p s b D$ genes encoding the D1 and D2 subunits, respectively, (3) Production of new protein subunits from the respective mRNA pools, (4) Incorporation of the newly synthesized protein copies into the PSII complex, and finally (5) Religation of redox cofactors and reactivation of PSII. In the repair process, two UV-B-specific effects are noteworthy. One is the FtsH protease dependent degradation of both D1 and D2 proteins (19). The other such feature is the presence and induction of UV-B-specific psbA gene copies in some cyanobacteria, such as Synechocystis 6803, Anabeana 7120, Gloeobacter violacous (22-24). Although UV-B-induced damage of DNA molecules and photosynthetic complexes obviously occurs in a parallel fashion, as shown by growth retardation under conditions when DNA lesions accumulate (25), there has not been a serious attempt in the literature to study the influence of DNA damage on the PSII repair cycle. The only indication for such an effect so far is the observation that the presence of a UV-C contamination from the UV-B source, which significantly enhances DNA damage, decreases the extent of PSII recovery associated with the D1 turnover (18). However, the molecular background of the mechanism that retards the protein synthesis has not been elucidated.

In the repair cycle of photodamaged PSII complexes de novo synthesis of damaged D1 and D2 protein subunits is a highly important step. As this includes the transcription and translation of several genes encoding D1, D2, chaperons, accessory proteins, etc. see $(20,21)$ we hypothesize that following UV-B stress there is a strong connection between the ability of cells to maintain damage free DNA molecules and to regain their photosynthetic activity.

In this study, we investigated the correlation of PSII damage and its protein synthesis-dependent repair with the concomitant DNA damage and its repair. Our results show that DNA repair is a prerequisite of efficient protein synthesis and maintenance of functional PSII.

\section{MATERIALS AND METHODS}

Cell cultures and UV-B treatment conditions. Synechocystis PCC6803 (denoted as Synechocystis hereafter) wild type and the $\Delta p h r A(\Delta \operatorname{slr} 0854)$ photolyase deficient mutant were grown in BG-11 medium, in an incuba-

1 tor with an orbital shaker $(120 \mathrm{rpm})$, in $3 \% \mathrm{CO}_{2}$-enriched atmosphere under constant $40 \mu \mathrm{mol} \mathrm{m}^{-2} \mathrm{~s}^{-1} \mathrm{PAR}$ at $30^{\circ} \mathrm{C}$.

The photolyase lacking mutant $(\Delta$ slr0854) was constructed by interrupting the slr0854 gene with a spectinomycin cassette.

For the experiments, $200 \mathrm{~mL}$ cultures were harvested by centrifugation $\left(6500 \mathrm{~g}, 5 \mathrm{~min}, 24^{\circ} \mathrm{C}\right)$ in their exponential growth phase, resuspended in fresh BG-11 medium at $6.5 \mu \mathrm{g} \mathrm{mL}^{-1}$ Chl concentration, and further incubated for an hour. The UV-B treatments were carried out at $30^{\circ} \mathrm{C}$, with continuous stirring in square glass containers in which the suspension formed a $2.5 \mathrm{~cm}$ high layer. UV-B radiation was provided by a Vilber Lourmat VL-215M lamp in combination with cellulose acetate filter (Clarfoil $0.1 \mathrm{~mm}$, cut off at $290 \mathrm{~nm}$ ) to screen out any possible UV-C radiation. The UV-B intensity was $3.0 \mathrm{~W} \mathrm{~m}^{-2}(\approx 8.0 \mu \mathrm{mol}$ $\mathrm{m}^{-2} \mathrm{~s}^{-1}$ ) at the surface of the cell suspension as measured with a ColeParmer radiometer (model 97503-00) equipped with a $312 \mathrm{~nm}$ sensor. Due to the high optical density of the cell suspension, the average UV-B irradiation intensity was only approximately $0.3 \mathrm{~W} \mathrm{~m}^{-2}(\approx$ $0.8 \mu \mathrm{mol} \mathrm{m}^{-2} \mathrm{~s}^{-1}$ ) within the cell suspension, as calculated by taking into account the absorption by the optically dense sample according to Rontó et al. (26). Before UV-B treatments, cells were kept for $30 \mathrm{~min}$ under $50 \mu \mathrm{mol} \mathrm{m}{ }^{-2} \mathrm{~s}^{-1}$ white light, which was also used as background illumination during the UV-B treatments, as well as during the recovery period following the UV-B treatments.

The radiation intensities for the white light and the UV-B illumination were measured using a LiCor Photometer (DMP Ltd.) equipped with a PAR sensor and a Cole-Parmer Radiometer equipped with a UV-B $(312 \mathrm{~nm})$ sensor, respectively.

Assessment of photosynthetic activity. Wild type and $\triangle p h r A$ mutant cells were exposed to UV-B light $\left(8 \mu \mathrm{mol} \mathrm{m}^{-2} \mathrm{~s}^{-1}\right)$ either in the absence, or in the presence of the protein synthesis inhibitor lincomycin $\left(300 \mu \mathrm{g} \mathrm{mL}^{-1}\right)$. The UV-B light was supplemented with white light (WL, $50 \mu \mathrm{mol} \mathrm{m} \mathrm{m}^{-2} \mathrm{~s}^{-1}$ ) in the initial phase of the experiments (UV-B + WL, for $270 \mathrm{~min}$ ). This was followed by a recovery period under white light only (WL) for $120 \mathrm{~min}$. In the final phase of the experiment, the UV-B exposure was repeated in the absence of white background illumination (UV-B) for $60 \mathrm{~min}$. In experiments, in which the protein synthesis inhibitor lincomycin was added to the cell cultures only UV-B + WL illumination was applied for $120 \mathrm{~min}$.

PSII activity during and after UV-B treatments and recovery periods was assessed by measuring the changes of variable Chl fluorescence values, as the initial amplitudes of the flash induced fluorescence signals $(F \mathrm{~V}=F \mathrm{~m}-F \mathrm{o})$ relative to the control $(t=0 \mathrm{~min})$ point reflect the relative amount of functional PSII complexes. The flash-induced $\mathrm{Chl}$ fluorescence measurements were performed with an FL 3000 Fluorometer (Photon Systems Instruments Ltd.), using $1 \mathrm{~mL}$ samples in the absence and presence of 3-(3,4-dichlorophenyl)-1, 1-dimethylurea (DCMU). Measurements were repeated on three biologically different samples at preset time points (see Fig. 1). The data were visualized and evaluated using the Fluorwin software, version 3.6.3.11 and Origin.

D1 protein analysis. Thylakoid membranes were isolated as described in Ref. (27) from samples taken right before the onset of UV-B + WL irradiation ( 0 min time point), at the end of the $270 \mathrm{~min}$ UV-B + WL treatment, at the end of the subsequent $120 \mathrm{~min}$ WL recovery period, as well as at the end of the final $60 \mathrm{~min}$ UV-B

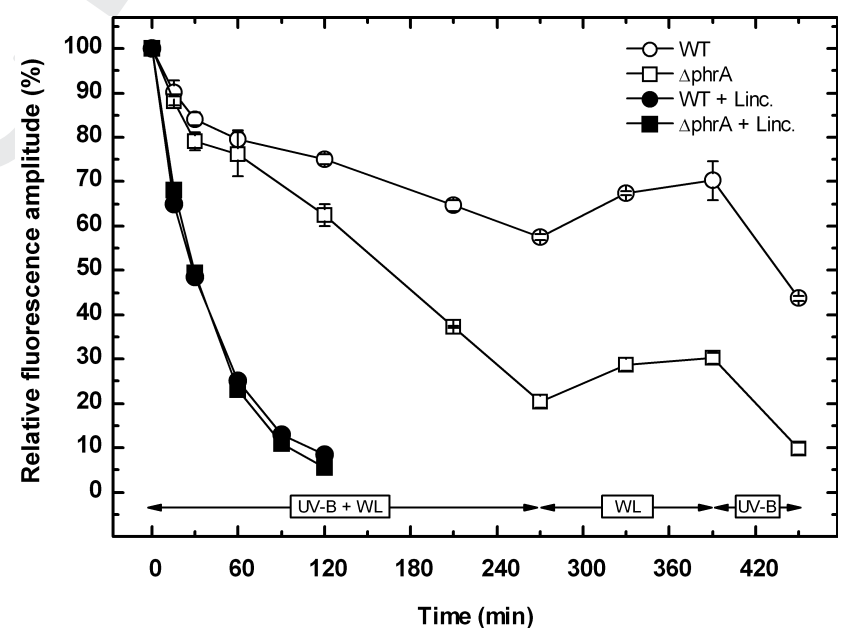

Figure 1. PSII activity changes, assessed by flash-induced Chl fluorescence, of Synechocystis cells in response to UV-B exposure. WT (circles) and the photolyase lacking $\triangle p h r A$ mutant (squares) were exposed to UV-B light $\left(8 \mu \mathrm{mol} \mathrm{m}^{-2} \mathrm{~s}^{-1}\right)$ either in the absence (open symbols) or in the presence (closed symbols) of the protein inhibitor lincomycin. The UV-B light was supplemented with white light (WL, $50 \mu \mathrm{mol} \mathrm{m}^{-2} \mathrm{~s}^{-1}$ ) in the initial phase of the experiment (UV-B + WL), which was followed by a recovery period under white light only (WL). In the final phase of the experiment, the UV-B exposure was repeated in the absence of white background illumination (UV-B). PSII activity was assessed by measuring the initial amplitude of flash-induced Chl fluorescence signals that reflects the amount functional PSII centers. The data are shown in percentage of the control value measured in untreated cells. The error bars indicate standards deviations obtained from three independent experiments. When error bars are not visible, they are either smaller than the size of the closed symbols, or overlap with the outline of the open symbols. 
treatment. Thylakoid samples, each equalized to contain $1 \mu \mathrm{g}$ of Chl, were separated by SDS-PAGE, on a $12 \%$ gel, blotted on nitrocellulose membrane and visualized with specific antibodies according to (19). Protein bands were quantified with the help of ImageJ (http://

2 rsbweb.nih.gov/ij/). The measurements were repeated on three biologically different samples and the mean values were used for assessing the changes in the D1 protein amounts.

Expression level of the psbA3 gene was assessed by $\mathrm{qPCR}$ as described earlier (28).

Isolation of genomic DNA. Genomic DNA was isolated using methods that minimize the risk of inducing single or double strand breaks. Cells of $15 \mathrm{~mL}$ samples were harvested and resuspended in $200 \mu \mathrm{L}$ of saturated $\mathrm{NaI}$ solution. After incubation for $10 \mathrm{~min}$ at $37^{\circ} \mathrm{C}, 1 \mathrm{~mL}$ water was added, and samples were centrifuged. The pellets were resuspended in $400 \mu \mathrm{L}$ of Tris buffer I (50 mm Tris, pH 8, $5 \mathrm{~mm}$ EDTA, $50 \mathrm{~mm}$ $\mathrm{NaCl})$ and $100 \mu \mathrm{L}$ of lysozyme $\left(50 \mathrm{mg} \mathrm{mL}^{-1}\right)$ was added. The suspension was incubated for $10 \mathrm{~min}$ at $37^{\circ} \mathrm{C}$ and then centrifuged $\left(5500 \mathrm{~g}, 4^{\circ}\right.$ C, $5 \mathrm{~min}$ ). The pellets were washed with $400 \mu \mathrm{L}$ Tris buffer I and centrifuged $\left(5500 \mathrm{~g}, 4^{\circ} \mathrm{C}, 5 \mathrm{~min}\right)$. The pellets were resuspended in $500 \mu \mathrm{L}$ Tris buffer I and $100 \mu \mathrm{L}$ of $\mathrm{N}$-lauryl-sarcosine $(10 \% \mathrm{w} / \mathrm{v}), 4 \mu \mathrm{L}$ of RNase A (10 mg mL $\left.{ }^{-1}\right)$ was added and kept for $20 \mathrm{~min}$ at $37^{\circ} \mathrm{C}$. From this point on samples were handled with extra care and wide bore pipette tips were used. $25 \mu \mathrm{L}$ of Proteinase $\mathrm{K}\left(20 \mathrm{mg} \mathrm{mL}^{-1}\right)$ was added and the samples were then incubated for $60 \mathrm{~min}$ at $60^{\circ} \mathrm{C}$, and centrifuged (17 $\left.500 \mathrm{~g}, 4^{\circ} \mathrm{C}, 20 \mathrm{~min}\right)$. The clear green supernatants were carefully transferred into new tubes and gently mixed on a tube rotator for 15-20 min with equal volume of Phenol-TE $\mathrm{pH}$ 8.0, and centrifuged $\left(15000 \mathrm{~g}, 4^{\circ} \mathrm{C}, 5 \mathrm{~min}\right)$. The upper phases were carefully transferred to new tubes and the phenol extraction was repeated. The DNA was precipitated with $1 / 9$ vol of $3 \mathrm{M} \mathrm{NaOAc}$ and $0.7 \mathrm{vol}$ of i-Propanol at $-20^{\circ} \mathrm{C}$ for at least $30 \mathrm{~min}$, centrifuged $\left(20000 \mathrm{~g}, 4^{\circ} \mathrm{C}, 1 \mathrm{~h}\right)$, and washed with $400 \mu \mathrm{L}$ of $70 \%$ ET-OH. The supernatant was discarded and the samples were left to dry on room temperature, and rehydrated in $20-30 \mu \mathrm{L}$ of water at $4^{\circ} \mathrm{C}$ for overnight.

Detection of $U V-B$ induced DNA damage by $q P C R$. This method is based on the assumption that biologically significant lesions block the action of Taq polymerase. Therefore, only the intact DNA molecules can be quantified using qPCR, and the extent of damage can be calculated from the virtually decreased amount of the DNA. Accordingly, UV-B-dependent decrease in amplified 16S rDNA was shown in Ref. (25). To enable exact determination of the extent of DNA damage, we carried out similar PCR reactions, but using qPCR. Keeping in mind that pyrimidine dimers are the most abundant type of lesions caused by UV-B (4), a $1 \mathrm{kbp}$ long region of the Synechocystis genome containing the most pyrimidine neighbors was selected using a custom made PERL script for amplification in a ABI SDS7000 qPCR equipment. A 50 bp long genomic sequence with the least number of these neighbors was used as an internal control and the relative apparent quantities were used for calculation of the probabilities of DNA lesions. The cells were harvested, washed, subjected to three freeze-thaw cycles and used in PCR reactions as templates like in colony-PCR.

Detection of UV-B-induced DNA damage by alkaline gel method. Pyrimidine dimers were detected by incubating gDNA with T4 Endonuclease V, which specifically cleaves the DNA molecule at pyrimidine dimer sites, causing single strand brakes (29). The resulting fragments were separated on a $0.6 \%$ alkaline agarose gel, previously soaked in alkaline electrophoresis buffer $(50 \mathrm{~m} \mathrm{NaOH}, 1 \mathrm{~mm}$ EDTA). The same solution was used as running buffer.

The presence of unrepaired pyrimidine dimers yields strand brakes leading to reduced size of DNA fragments, which show up as a smear on the alkaline gel. The relative decrease in the apparent average length is representative of the encountered direct UV-B damages and also allows for quantitative determination of those. Nucleic acids were visualized with the help of ethidium-bromide. Gel images were evaluated using custom made software written in MATLAB for establishing the average/mean fragment lengths according to the calculations in (30).

The two DNA damage quantification methods complement each other well. The qPCR-based assay is faster and simpler than the alkaline gel method, and it shows the sum of all the lesions; while the alkaline gel is more sensitive and allows selective detection of pyrimidine dimers.

Significance in dataset variability was tested with one-way ANOVA, at $P=0.05$.

\section{RESULTS AND DISCUSSION}

\section{Effect of the lack of photolyase on UV-B induced activity loss of PSII}

We aimed to investigate the role of UV-B-induced DNA lesions in PSII activity loss during UV-B stress. To achieve this, we compared the changes in the amount of functional PSII, quantified by flash-induced Chl fluorescence measurements in UV-B exposed WT Synechocystis and its photolyase deficient mutant $(\Delta p h r A)$, which is defective in its DNA repair capability.

In the initial phase of the UV-B treatment, which was performed in the presence of $50 \mu \mathrm{mol} \mathrm{m} \mathrm{m}^{-2} \mathrm{~s}^{-1}$ visible light, the $\Delta p h r A$ mutant lost its PSII activity somewhat faster than the WT. After $120 \mathrm{~min}$ of UV-B + WL treatment, the loss of PSII activity became significantly more pronounced in the $\Delta p h r A$ mutant than in the WT cells $(F=0.009$, at $P=0.05)$, in which protein synthesis-dependent PSII repair is functional (Fig. 1 open symbols). This large difference in PSII activity was retained during the subsequent exposure to UV-B + WL, and after $270 \mathrm{~min}$ the amount of active PSII decreased to 60 and $20 \%$ of their initial values in the WT and $\triangle p h r A$ cells, respectively (Fig. 1 open circles and open squares).

When the cells were kept under visible light following the UV-B + WL treatment, the PSII activity partially recovered and after $120 \mathrm{~min}$ it reached 70 and $30 \%$ of the initial values in the WT and the $\Delta p h r A$ mutant, respectively. When the cells were subsequently exposed to UV-B light in the absence of background visible light, PSII activity dropped rapidly to as low as $10 \%$ of its original level in the $\Delta p h r A$ mutant in $60 \mathrm{~min}$, whereas in the WT it dropped only to $45 \%$ of its initial value (Fig. 1 open squares and open circles, respectively).

When PSII repair was blocked by the protein synthesis inhibitor lincomycin, the loss of PSII was accelerated in both strains and decreased in a parallel fashion to a value lower than $10 \%$ of their initial values in $120 \mathrm{~min}$ (Fig. 1 closed symbols). In the presence of lincomycin, the loss of activity reflects the efficiency of PSII photodamage in itself without the influence of the protein synthesis dependent repair. Therefore, the identical inhibition course of PSII in the WT and $\Delta$ phrA mutant cells in the presence of lincomycin shows that the lack of DNA repair capacity does not modify the UV-B sensitivity of the PSII complex. The different extent of activity loss in the absence and presence of lincomycin in the same strain reflects the efficiency of protein synthesis dependent PSII repair during the light treatment. The difference between the inhibition curves measured in the absence and presence of lincomycin at $120 \mathrm{~min}$ is significantly $(F=0.012$, at $P=0.05)$ smaller in the $\Delta p h r A$ mutant than in the WT (Fig. 1). Further into the UV-B + WL treatment $(210$ and $270 \mathrm{~min}$ ), when the PSII activity in the presence of lincomycin is close to zero, the difference between the activities of the WT and the $\triangle p h r A$ mutant increases even more. These data show that PSII damage is repaired less efficiently in the absence of photolyase in the $\Delta p h r A$ mutant cells than in the WT cells, which have active photolyase.

\section{Effect of the lack of photolyase on UV-B-induced D1 protein loss}

UV-B-induced inactivation of PSII function is accompanied with the damage and degradation of the D1 subunit of the PSII 


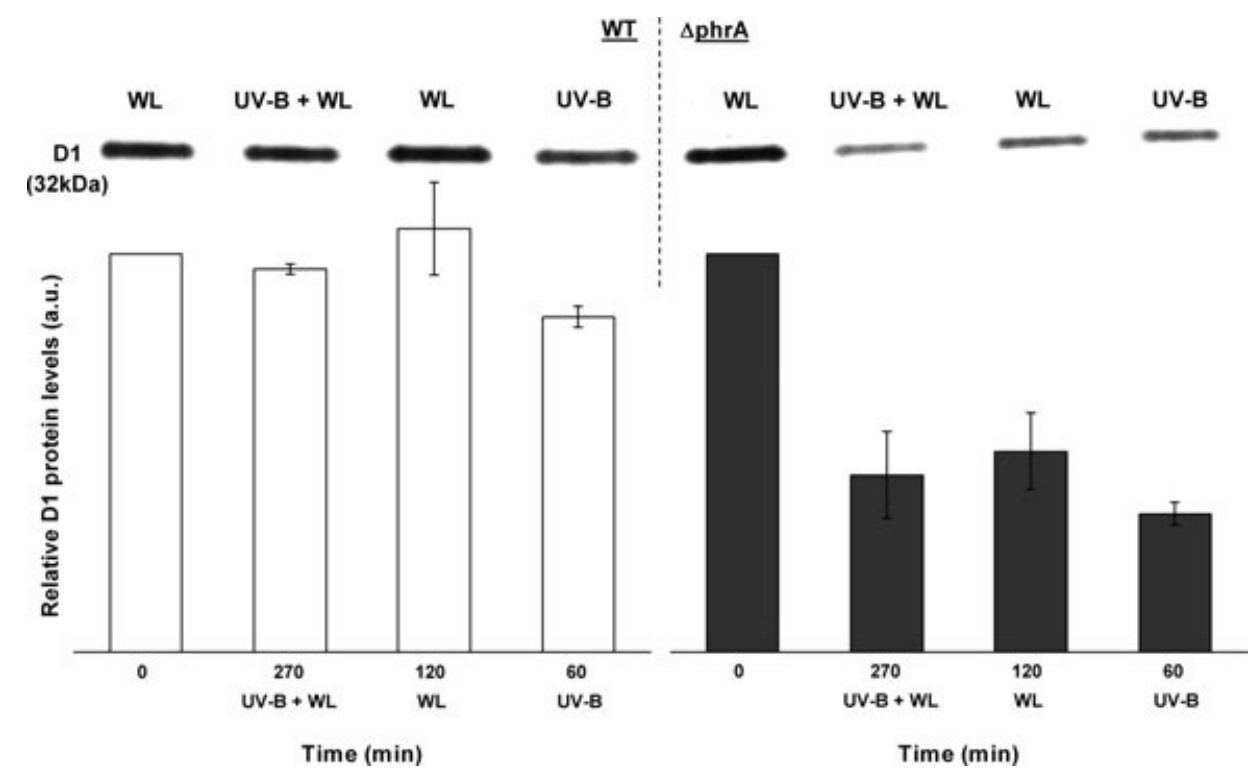

Figure 2. Response of D1 protein to UV-B treatment in WT and $\Delta p h r A$ cells. Cells were exposed to 270 min of $8 \mu \mathrm{mol} \mathrm{m}^{-2} \mathrm{~s}^{-1} \mathrm{UV}-\mathrm{B}$, in the presence $50 \mu \mathrm{mol} \mathrm{m}{ }^{-2} \mathrm{~s}^{-1}$ white light (UV-B $+\mathrm{WL}$ ), followed by a 120 -min WL only recovery period, and an additional UV-B only (UV-B) exposure. Isolated thylakoid membranes from samples taken during the treatment were separated by SDS-PAGE. D1 proteins were detected and visualized via immunoblotting. Protein bands were quantified with ImageJ and D1 amounts are shown relative to the untreated control samples $(0$ min $) . n=3$.

reaction center (18,31). When low intensity white light is applied simultaneously with UV-B illumination, it helps to ameliorate the UV-B-induced activity loss of PSII through enhanced protein turnover (32). Changes in D1 protein levels during the UV-B treatment (Fig. 2) corroborate the fluorescence data. The mutant cells lost a large portion of their D1 pool during UV-B stress, and were unable to recover it even in the absence of UV-B (Fig. 2 right panel), whereas D1 levels in WT cells were much less affected under the same treatment (Fig. 2. left panel), being significantly $(F=0.0419$, at $P=0.05)$ higher than in the $\Delta p h r A$ cells.

Effect of the lack of photolyase on UV-B-induced psbA mRNA response

The prerequisite of efficient PSII protein repair is the availability of abundant $p s b A$ mRNA pool for translation of D1, as well as transcription of other genes whose protein products, such as D2, the FtsH protease, etc. $(18,19,33,34)$ are required for PSII repair. In Synechocystis, the $p s b A 3$ copy of the $p s b A$ family serves as a UV stress gene, and its UV-B-induced transcription contributes significantly to the increase of the total $p s b A$ mRNA pool (22). Therefore, we used the $p s b A 3$ transcript abundance as a marker to evaluate the effects of photolyase deactivation on UV-B-induced responses at the transcript level of genes essential for PSII repair. UV-B light highly induces the $p s b A 3$ gene both in the WT and the $\Delta p h r A$ cells during the first phase of UV-B exposure reaching a steady-state level after 60-120 min (Fig. 3). When UV-B illumination was stopped after $270 \mathrm{~min}$ of treatment and cells were exposed to visible light alone the $p s b A 3$ transcript level rapidly decreased in the WT cells, and was inducible again by subsequent UV-B exposure in the absence of visible background light.

In contrast, in the $\triangle p h r A$ cells the $p s b A 3$ mRNA pool did not respond to the lack of the UV-B stimulus in the presence of background visible light, or to a repeated UV-B exposure. No significant $(F=0.744$, at $P=0.05$ ) change could be observed from the level that was reached at the end of the UV-B plus visible light treatment (Fig. 3). This behavior led us to assume that in the absence of the main DNA repair facilitator photolyase, the $\Delta p h r A$ cells accumulate so many UV-B-induced DNA damages that prevent the transcription of not only $p s b A 3$ but also of those genes whose protein products are needed to degrade the already existing $\mathrm{m} R N A \mathrm{~s}$.

\section{Quantification of UV-induced DNA damage}

In another cyanobacterium, Anabaena variabilis, Rastogi et al. (25) have shown that DNA damages accumulated in a UV-B

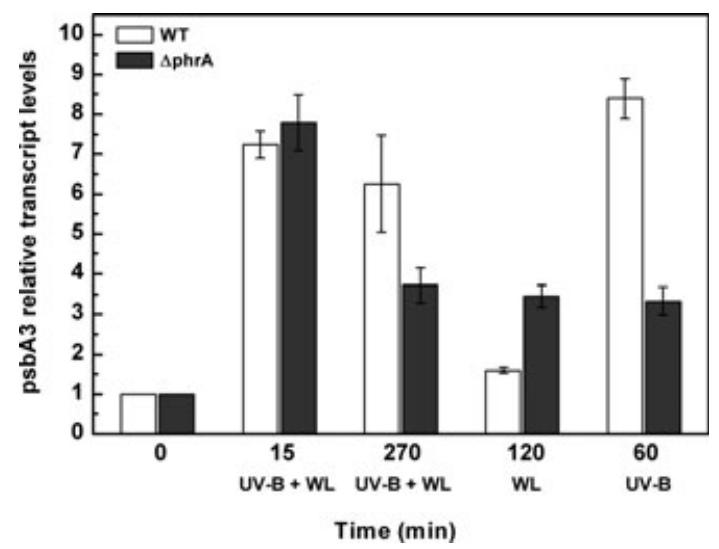

Figure 3. Changes of relative $p s b A 3$ transcript levels in WT and $\triangle p h r A$ cells. Cells were exposed to $8 \mu \mathrm{mol} \mathrm{m} \mathrm{m}^{-2} \mathrm{~s}^{-1}$ UV-B in the presence of $50 \mu \mathrm{mol} \mathrm{m} \mathrm{m}^{-2} \mathrm{~s}^{-1}$ white light (UV-B + WL) for $270 \mathrm{~min}$, followed by a 120 -min WL $\left(50 \mu \mathrm{mol} \mathrm{m}^{-2} \mathrm{~s}^{-1}\right)$ only recovery period and then a 60 -min UV-B $\left(8 \mu \mathrm{mol} \mathrm{m}{ }^{-2} \mathrm{~s}^{-1}\right)$ only treatment. The columns represent the induction levels of $p s b A 3$, after normalization to the transcript amount of the $\operatorname{rnpB}$ (slr1311) housekeeping gene of Synechocystis, coding for the RNase P subunit B. $n=3$. 
dose-dependent manner. We used two different methods to assess the extent of UV-induced DNA damage. Our qPCR-based method, described in the Materials and Methods, makes possible to determine the average number of DNA lesions without specifying the type of the lesions. In the WT cells, there was no significant $(F=0.724$. at $P=0.05)$ accumulation of DNA damages during the UV-B treatment with concomitant visible light present, and the detected average DNA damage remained below 0.1-0.2 lesions per $1 \mathrm{~kb}$ long DNA segment (Fig. 4). In contrast, in the $\triangle p h r A$ cells DNA lesions gradually accumulated reaching ca 1 lesion in average per $1 \mathrm{~kb}$ long DNA segment after 270 min UV-B plus visible light treatment (Fig. 4). The level of DNA damage was maintained during the recovery period, which shows that DNA repair is irreversibly inhibited in the absence of photolyase in the $\Delta p h r A$ mutant. Although cyanobacteria possess an excision repair mechanism that eliminates UV-induced pyrimidine dimers in the absence of photoreactivating blue/UV-A light (see Ref. [35]), the efficiency of excision repair seems to be negligible under our conditions. This could be due to the slow

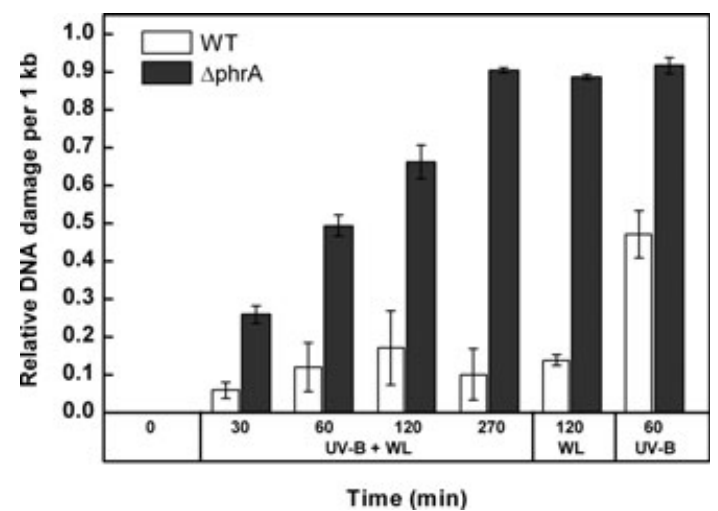

Figure 4. qPCR assessment of DNA damage. WT and $\triangle p h r A$ cells were exposed to $8 \mu \mathrm{mol} \mathrm{m} \mathrm{m}^{-2} \mathrm{~s}^{-1} \mathrm{UV}-\mathrm{B}$ in the presence of $50 \mu \mathrm{mol} \mathrm{m} \mathrm{m}^{-2} \mathrm{~s}^{-1}$ white light (UV-B + WL) for $270 \mathrm{~min}$, followed by a $120 \mathrm{~min}$ WL $\left(50 \mu \mathrm{mol} \mathrm{m} \mathrm{m}^{-2} \mathrm{~s}^{-1}\right)$ only recovery period and then a 60 -min UV-B $\left(8 \mu \mathrm{mol} \mathrm{m} \mathrm{m}^{-2} \mathrm{~s}^{-1}\right)$ only treatment. The columns represent the number of DNA polymerase hindering lesions on a $1 \mathrm{~kb}$ long DNA sequence. $n=2$. response of the excision repair system as indicated by the observation that $15 \mathrm{~h}$ was required for removal of pyrimidine dimers by excision repair in another cyanobacterium Synechocystis PCC 6308 (35). In addition, it has been shown that the absence of the photolyase enzyme inhibits excision repair in Saccharomyces cerevisiae and Escherichia coli (36). The interaction of photolyase dependent and excision repair appears to be a general phenomenon (36) and can explain the irreversible inhibition of DNA repair under our conditions (Fig. 4).

During the second phase of UV-B illumination, which was performed in the absence of background visible light the level of average DNA damages was also induced in the WT cells. This is most likely due to the absorption of the second cofactor of the Synechocystis CPD photolyase, 7,8-didemethyl-8-hydroxy-5deazariboflavin (8-HDF) in the $430-450 \mathrm{~nm}$ wavelength range (37), which is absent in the UV-B alone illumination protocol. Therefore, the activity of this particular photolyase is lower if no white light is present, leaving room for the accumulation of UV-B-induced DNA damages.

The average gene length in the Synechocystis genome is about $1 \mathrm{~kb}$. Thus, the observed 1 DNA lesion/kb implies that by the end of the UV-B treatment virtually all genes in the genome of the $\Delta p h r A$ mutant could have a lesion that can stop transcription under the applied irradiation conditions.

The qPCR method cannot discriminate among the different types of UV-induced DNA modifications, and it approximates the quantity of all sorts of DNA damages that could potentially impair gene expression. Therefore, we also applied a method that can specifically detect pyrimidine dimers that represent the most abundant type of UV-B-induced DNA lesion. We treated gDNA isolated from UV-B-treated cells with T4 endonuclease V, which produces single strand brakes at pyrimidine dimer sites, and separated the single stranded DNA fragments using alkaline gel. Quantification of the separated fragments carried out via analysis of the gel images with the help of a Matlab software, designed in our laboratory, resulted in DNA-damage amounts (Fig. 5), very similar to those detected by the qPCR method. The high degree overlap of the qPCR and alkaline gel data sets indicates that the overwhelming majority of the DNA lesions which accumulate during UV-B stress are in fact pyrimidine dimers.
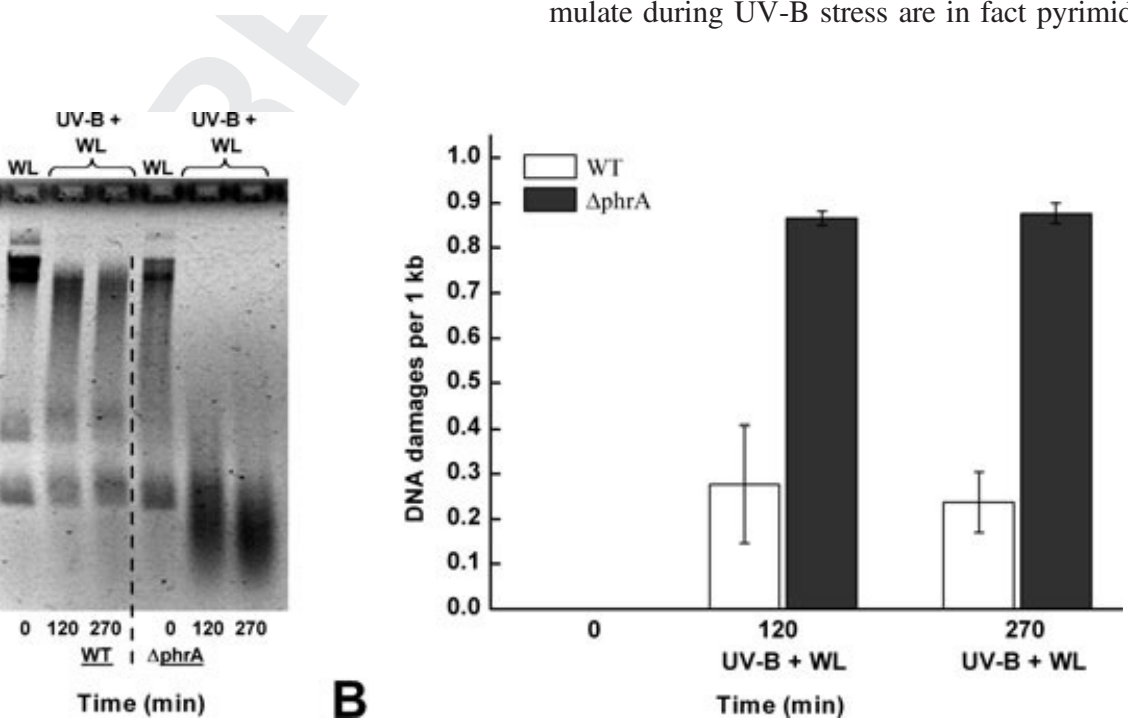

Figure 5. Alkaline gel assessment of DNA damage. Isolated gDNA from UV-B-treated WT and $\Delta p h r A$ cells was digested with T4 Endonuclease V and separated on alkaline gels. The gels were neutralized and soaked in ethidium-bromide for visualization. Panel A: gDNA from WT and $\Delta p h r A$ cells. Panel B: Calculated amount of DNA lesions. $n=3$. 


\section{Concluding remarks}

The results described here represent the first demonstration that UV-B-induced DNA damage affects photosynthetic functions, and show that the absence of the photolyase enzyme encoded by the phrA gene enhances photodamage of PSII in Synechocystis 6803 cells. This effect is caused by the accumulation of unrepaired DNA lesions, which give rise to inefficient transcription of $p s b A$ and other key genes of PSII repair, leading to enhanced loss of the D1 reaction center protein and photosynthetic activity during UV-B irradiation. Therefore, the DNA and PSII repair cycles, which represent two highly important defense mechanisms against UV-B-induced damage in photosynthetic organisms, are directly connected (Scheme 1).

The D1 subunit of the PSII complex is the protein with the highest turnover rate in oxygenic photosynthetic organisms, therefore accumulation of transcription limiting DNA lesions represent a key target for the PSII repair cycle. Our data also show that when UV-B exposure occurs in the presence of visible light and at temperatures close to the optimal growth conditions the DNA repair capacity of the photolyase enzyme is sufficient to keep DNA damage at a sufficiently low level that does not interfere with PSII repair. The effect of DNA repair limitation on

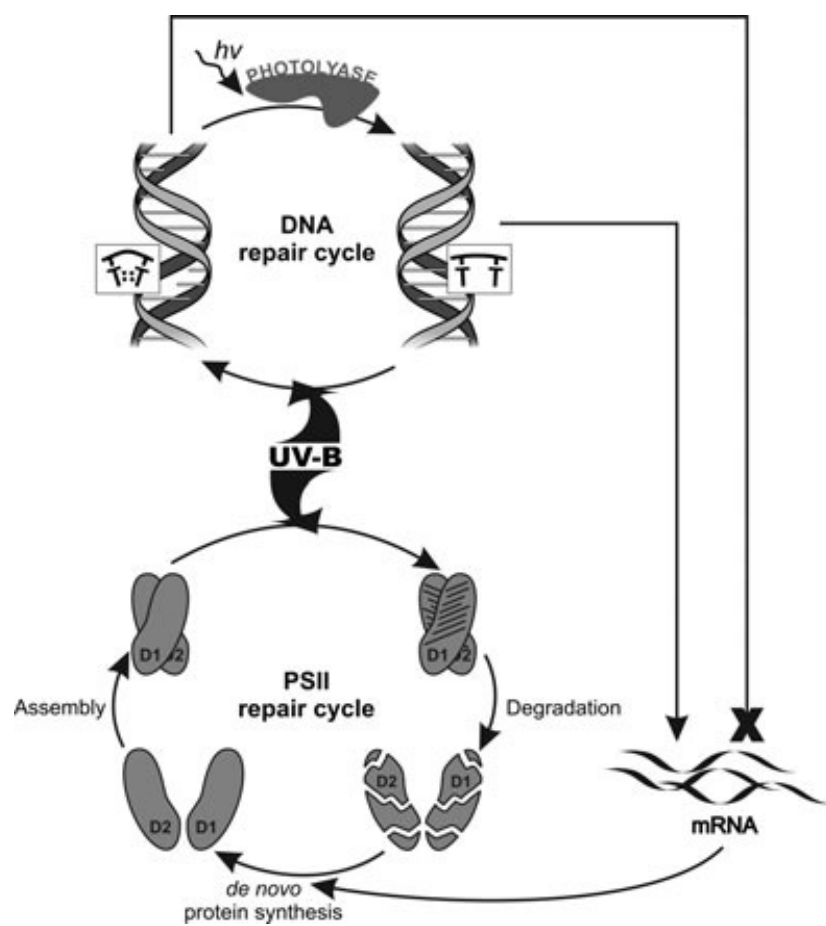

Scheme 1. Interaction of DNA damage repair and Photosystem-II damage-repair cycles in photosynthetic organisms. UV-B radiation damages DNA by inducing cyclobutane pyrimidine dimers, which block polymerases and prevent the translation of mRNA. These DNA lesions can be restored by the action of the light-activated enzyme, photolyase, which breaks up the pyrimidine dimers and ensures the translation of DNA into functional mRNA. UV-B damage of Photosystem-II reaction center complex leads to the degradation of the D1 (and D2) reaction center subunits, which have to be resynthesized to restore Photosystem-II structure and function. Protein synthesis can proceed only if sufficient amount of mRNA is available for the translation of new D1 (and D2) subunits, which incorporate into the PSII complex and restore its activity. This critical step of the PSII repair cycle is blocked if unrepaired DNA lesions accumulate and prevent mRNA formation.
PSII repair becomes significant when the photolyase enzyme is inactivated or inhibited. Low temperature is known to decrease the efficiency of photolyase $(38,39)$ and generally the photoreactivation of tymidine dimers (25), which leads to decreased DNA repair activity. Therefore, limitation of DNA repair on PSII function may occur under physiological relevant conditions, such as in polar and alpine environments where elevated UV exposure occurs in combination with low temperature.

Acknowledgements-This work was supported by the Hungarian granting agency OTKA (K-84257) and the Hungarian-New Zealand TÉT program (10_10-1-2011-0003). The authors owe special thanks to Evelyne Sage (Institut Curie, CNRS) for valuable discussions.

\section{REFERENCES}

1. Ravanat, J.-L., T. Douki and J. Cadet (2001) Direct and indirect effects of UV radiation on DNA and its components. J. Photochem. Photobiol., B 63, 88-102.

2. Markovitsi, D., T. Gustavsson and A. Banyasz (2010) Absorption of UV radiation by DNA: Spatial and temporal features. Mutat. Res. 704, 21-28.

3. Weber, S. (2005) Light-driven enzymatic catalysis of DNA repair: A review of recent biophysical studies on photolyase. Biochim. Biophys. Acta 1707, 1-23.

4. Cadet, J., C. Anselmino, T. Douki and L. Voituriez (1992) New trends in photobiology. Photochemistry of nucleic acids in cells. J. Photochem. Photobiol. B 15, 277-298.

5. Sancar, A. (2008) Structure and function of photolyase and in vivo enzymology: 50th anniversary. J. Biol. Chem. 283, 32153-32157.

6. Hitomi, K., K. Okamoto, H. Daiyasu, H. Miyashita, S. Iwai, H. Toh, M. Ishiura and T. Todo (2000) Bacterial cryptochrome and photolyase: Characterization of two photolyase-like genes of Synechocystis sp. PCC6803. Nucleic Acids Res. 28, 2353-2362.

7. Ng, W.-O., R. Zentella, Y. Wang, J.-S. A. Taylor and H. B. Pakrasi (2012) phrA, the major photoreactivating factor in the cyanobacterium Synechocystis sp. strain PCC 6803 codes for a cyclobutanepyrimidine-dimer-specific DNA photolyase. Arch. Microbiol. 173, $412-417$.

8. Ng, W.-O. and H. B. Pakrasi (2001) DNA photolyase homologs are the major UV resistance factors in the cyanobacterium Synechocystis sp. PCC 6803. Mol. Gen. Genet. 264, 924-930.

9. Lao, K. and A. N. Glazer (1996) Ultraviolet-B photodestruction of a light-harvesting complex. Proc. Natl. Acad. Sci. $U$ S A 93, 5258-5263.

10. Bornman, J. F. (1989) Target sites of UV-B radiation in photosynthesis of higher plants. J. Photochem. Photobiol. B4, 145-158.

11. Renger, G., M. Völker, H. J. Eckert, R. Fromme, S. Hohm-Veit and P. Graber (1989) On the mechanism of photosystem II deterioration by UV-B irradiation. Photochem. Photobiol. 49, 97-105.

12. Vass, I., L. Sass, C. Spetea, A. Bakou, D. Ghanotakis and V. Petrouleas (1996) UV-B induced inhibition of photosystem II electron transport studied by EPR and chlorophyll fluorescence. Impairment of donor and acceptor side components. Biochemistry 35, 8964-8973.

13. Vass, I., D. Kirilovsky and A.-L. Etienne (1999) UV-B radiationinduced donor- and acceptor-side modifications of photosystem II in the cyanobacterium Synechocystis sp. PCC 6803. Biochemistry 38, 12786-12794.

14. Hakala, M., I. Tuominen, M. Keranen, T. Tyystjarvi and E. Tyystjarvi (2005) Evidence for the role of the oxygen-evolving manganese complex in photoinhibition of photosystem II. Biochim. Biophys. Acta 1706, 68-80.

15. Greenberg, B. M., V. Gaba, O. Canaani, S. Malkin, A. K. Mattoo and M. Edelman (1989) Separate photosensitizers mediate degradation of the $32-\mathrm{kDa}$ photosystem II reaction centre protein in visible and UV spectral regions. Proc. Natl. Acad. Sci. U S A 86, 6617-6620.

16. Melis, A., J. A. Nemson and M. A. Harrison (1992) Damage to functional components and partial degradation of photosystem II 
reaction center proteins upon chloroplast exposure to ultraviolet-B radiation. Biochim. Biophys. Acta 1100, 312-320.

17. Friso, G., C. Spetea, G. M. Giacometti, I. Vass and R. Barbato (1994) Degradation of photosystem II reaction center D1-protein induced by UVB irradiation in isolated thylakoids. Identification and characterization of $\mathrm{C}$ - and $\mathrm{N}$-terminal breakdown products. Biochim. Biophys. Acta 1184, 78-84.

18. Sass, L., C. Spetea, Z. Máté, F. Nagy and I. Vass (1997) Repair of UV-B induced damage of photosystem II via de novo synthesis of the D1 and D2 reaction centre subunits in Synechocystis sp. PCC 6803. Photosynth. Res. 54, 55-62.

19. Cheregi, O., C. Sicora, P. B. Kós, M. Barker, P. J. Nixon and I. Vass (2007) The role of the FtsH and Deg proteases in the repair of UV-B radiation-damaged photosystem II in the cyanobacterium Synechocystis PCC 6803. Biochim. Biophys. Acta 1767, 820-828.

20. Aro, E.-M., I. Virgin and B. Andersson (1993) Photoinhibition of photosystem II. Inactivation, protein damage and turnover. Biochim. Biophys. Acta 1143, 113-134.

21. Nixon, P. J., F. Michoux, J. Yu, M. Boehm and J. Komenda (2010) Recent advances in understanding the assembly and repair of photosystem II. Ann. Bot. 106, 1-16.

22. Máté, Z., L. Sass, M. Szekeres, I. Vass and F. Nagy (1998) UV-B induced differential transcription of $p s b A$ genes encoding the D1 protein of photosystem II in the cyanobacterium Synechocystis 6803. J. Biol. Chem. 273, 17439-17444.

23. Sicora, C., S. E. Appleton, C. M. Brown, J. Chung, J. Chandler, A. M. Cockshutt, I. Vass and D. A. Campbell (2006) Cyanobacterial psbA families in Anabaena and Synechocystis encode trace, constitutive and UVB-induced D1 isoforms. Biochim. Biophys. Acta $\mathbf{1 7 5 7}$ 47-56.

24. Sicora, C. I., C. M. Brown, O. Cheregi, I. Vass and D. A. Campbell (2008) The $p s b A$ gene family responds differentially to light and UVB stress in Gloeobacter violaceus PCC 7421, a deeply divergent cyanobacterium. Biochim. Biophys. Acta 1777, 130-139.

25. Rastogi, R. J., S. P. Singh, D.-P. Häder and R. P. Sinha (2011) Ultraviolet-B-induced DNA damage and photorepair in the cyanobacterium Anabaena variabilis PCC 7937. Environ. Exp. Bot. 74 280-288.

26. Rontó, Gy, A. Fekete, S. Gáspár and K. Módos (1989) Action spectra for photoinduced inactivation of bacteriophage $\mathrm{T} 7$ sensitized by 8-methoxypsoralen and angelicin. J. Photochem. Photobiol. 3B, 497-507.

27. Komenda, J. and J. Barber (1995) Comparison of $p s b O$ and $p s b H$ deletion mutants of Synechocystis PCC 6803 indicates that degradation of $\mathrm{D} 1$ protein is regulated by the $\mathrm{Q}_{\mathrm{B}}$ site and dependent on protein synthesis. Biochemistry 34, 9625-9631.
28. Kós, P. B., Zs. Deák, O. Cheregi and I. Vass (2008) Differential regulation of $p s b A$ and $p s b D$ gene expression, and the role of the different D1 protein copies in the cyanobacterium Thermosynechococcus elongatus BP-1. Biochim. Biophys. Acta 1777, 74-83.

29. Higgins, K. M. and R. S. Lloyd (1987) Purification of the T4 endonuclease V. Mutat. Res. 183, 117-121.

30. Sutherland, B. M., A. G. Georgakilas, P. V. Bennett, J. Laval and J. C. Sutherland (2003) Quantifying clustered DNA damage induction and repair by gel electrophoresis, electronic imaging and number average length analysis. Mutat. Res. 531, 93-107.

31. Friso, G., I. Vass, C. Spetea, J. Barber and R. Barbato (1995) UV-B-induced degradation of the D1 protein in isolated reaction centres of photosystem II. Biochim. Biophys. Acta 1231, 41-46.

32. Sicora, C., Z. Máté and I. Vass (2003) The interaction of visible and UV-B light during photodamage and repair of photosystem II. Photosynth. Res. 75, 127-137.

33. Viczián, A., Z. Máté, F. Nagy and I. Vass (2000) UV-B induced differential transcription of $p s b D$ genes encoding the D2 protein of photosystem II in the cyanobacterium Synechocystis 6803. Photosynth. Res. 64, 257-266.

34. Cadoret, J.-C., B. Rousseau, I. Perewoska, C. Sicora, O. Cheregi, I. Vass and J. Houmard (2005) Cyclic nucleotides, the photosynthetic apparatus and response to a UV-B stress in the cyanobacterium Synechocystis sp. PCC 6803. J. Biol. Chem. 280, 33935-33944.

35. O'Brien, P. A. and J. A. Houghton (1982) Photoreactivation and excision repair of UV induced pyrimidine dimers in the unicellular cyanobacterium gloeocapsa alpicola (Synechocystis PCC 6308). Photochem. Photobiol. 35, 359-364.

36. Sancar, G. B. and F. W. Smith (1989) Interactions between yeast photolyase and nucleotide excision repair proteins in Saccharomyces cerevisiae and Escherichia coli. Mol. Cell. Biol. 9, 4767-4776.

37. Yasui, A., A. P. M. Eker, S. Yasuhira, H. Yajima, T. Kobayashi, M. Takao and A. Oikawa (1994) A new class of DNA photolyases present in various organisms including aplacental mammals. EMBO J. 13, 6143-6151.

38. Macfadyen, E. J., C. E. Williamson, G. Grad, M. Lowery, W. H. Jeffrey and D. L. Mitchell (2004) Molecular response to climate change: Temperature dependence of UV-induced DNA damage and repair in the freshwater crustacean Daphnia pulicaria. Glob. Change Biol. 10, 408-416.

39. Lamare, M. D., M. F. Barker, M. P. Lesser and C. Marschall (2006) DNA photorepair in echinoid embryos: Effects of temperature on repair rate in Antarctic and non-Antarctic species. J. Exp. Biol. 209, 5017-5028. 


\section{Author Query Form}

\section{Journal: $\quad$ PHP}

Article: $\quad 12012$

Dear Author,

During the copy-editing of your paper, the following queries arose. Please respond to these by marking up your proofs with the necessary changes/additions. Please write your answers on the query sheet if there is insufficient space on the page proofs. Please write clearly and follow the conventions shown on the attached corrections sheet. If returning the proof by fax do not write too close to the paper's edge. Please remember that illegible mark-ups may delay publication. Many thanks for your assistance.

\begin{tabular}{|l|l|l|}
\hline Query reference & Query & Remarks \\
\hline 1 & AUTHOR: $120 \mathrm{rpm}:$ please replace this with the correct $g$ value. & \\
\hline 2 & $\begin{array}{l}\text { AUTHOR: Please check this website address and confirm that it is correct. (Please } \\
\text { note that it is the responsibility of the author(s) to ensure that all URLs given in } \\
\text { this article are correct and useable.) }\end{array}$ & \\
\hline
\end{tabular}




\section{Proof Correction Marks}

Please correct and return your proofs using the proof correction marks below. For a more detailed look at using these marks please reference the most recent edition of The Chicago Manual of Style and visit them on the Web at: http://www.chicagomanualofstyle.org/home. html

\begin{tabular}{|c|c|c|}
\hline Instruction to typesetter & Textual mark & Marginal mark \\
\hline Leave unchanged & $\cdots$ under matter to remain & (stet) \\
\hline $\begin{array}{l}\text { Insert in text the matter } \\
\text { indicated in the margin }\end{array}$ & $\wedge$ & $\begin{array}{l}\wedge \text { followed by new } \\
\text { matter }\end{array}$ \\
\hline Delete & $\sigma_{\text {through single character, rule or underline }}$ & matter \\
\hline $\begin{array}{l}\text { Substitute character or } \\
\text { substitute part of one or } \\
\text { more word(s) }\end{array}$ & $\begin{array}{l}\mathcal{I} \text { through all characters to be deleted } \\
K \text { through letter or } \\
\end{array}$ & $\begin{array}{l}\text { new character } \lambda \text { or } \\
\text { new characters } \lambda\end{array}$ \\
\hline Change to italics & — under matter to be changed & ital \\
\hline Change to capitals & $\equiv$ under matter to be changed & caps \\
\hline Change to small capitals & $=$ under matter to be changed & (5e) \\
\hline Change to bold type & $\approx$ under matter to be changed & (4f) \\
\hline Change to bold italic & $\bar{\sim}$ under matter to be changed & offital \\
\hline Change to lower case & B & (b) \\
\hline Insert superscript & $\checkmark$ & $\begin{array}{l}\vee \text { under character } \\
\text { e.g. } \vee\end{array}$ \\
\hline Insert subscript & $\wedge$ & $\begin{array}{l}\wedge \text { over character } \\
\text { e.g. } 1\end{array}$ \\
\hline Insert full stop & $\odot$ & $\odot$ \\
\hline Insert comma & $\hat{\jmath}$ & $\hat{\jmath}$ \\
\hline Insert single quotation marks & $\sqrt{2}$ & 22 \\
\hline Insert double quotation marks & $\ddot{v}$ & 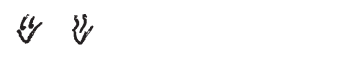 \\
\hline Insert hyphen & $=$ & $=$ \\
\hline Start new paragraph & 4 & 4 \\
\hline Transpose & $\sqcup$ & $\sqcup$ \\
\hline Close up & linking 2 characters & 2 \\
\hline $\begin{array}{l}\text { Insert or substitute space } \\
\text { between characters or words }\end{array}$ & \# & \# \\
\hline $\begin{array}{l}\text { Reduce space between } \\
\text { characters or words }\end{array}$ & J & J \\
\hline
\end{tabular}

